\title{
Frequency of Chlamydia trachomatis in Ureaplasma-positive healthy women attending their first prenatal visit in a community hospital in Sapporo, Japan
}

Tomohiro Yamazaki ${ }^{1}$, Megumi Matsumoto ${ }^{1}$, Junji Matsuo', Kiyotaka Abe $^{2}$, Kunihiro Minami ${ }^{2}$ and Hiroyuki Yamaguchi*

\begin{abstract}
Background: Although Chlamydia trachomatis is the most commonly reported pathogen that causes urogenital infection such as urethritis or cervicitis, Ureaplasma parvum and Ureaplasma urealyticum, which are commensals in the genital tract, have also now been recognized as contributors to urogenital infection. However, whether the presence of either U. parvum or U. urealyticum is related to that of $C$. trachomatis in the urogenital tract remains unknown. We therefore attempted to estimate by PCR the prevalence of C. trachomatis, U. parvum and U. urealyticum in endocervical samples obtained from healthy women attending their first prenatal visit in Sapporo, Japan.

Methods: The samples were taken from 303 apparently healthy women, and the extracted DNAs $(n=280)$ were used for PCR detection targeting C. trachomatis, U. parvum and U. urealyticum. Statistical analysis of the data was performed by Fisher's exact test.

Results: PCR detection revealed that the prevalence of C. trachomatis, U. parvum and U. urealyticum was $14.3 \%$ (40/280), 41.7\% (117/280) and 8.9\% (25/280), respectively. C. trachomatis ompA genotype D was most frequently identified. Surprisingly, either C. trachomatis or Ureaplasma spp. was detected in almost half of the healthy women. Mixed infection of $C$. trachomatis with either $U$. parvum or $U$. urealyticum was also observed in $9.2 \%(26 / 280)$ of the women. There was a significant association between C. trachomatis and either U. parvum $(p=0.023)$ or Ureaplasma total $(p=0.013)$, but not $U$. urealyticum $(p=0.275)$.

Conclusion: This study demonstrated that the presence of Ureaplasma had a significant effect on the presence of C. trachomatis in the genital tract of healthy women, suggesting that mixed infection is an important factor in bacterial pathogenesis in the genital tract.
\end{abstract}

Keywords: Chlamydia trachomatis, Ureaplasma urealyticum, Ureaplasma parvum, Mixed infection, PCR

\section{Background}

Urogenital tract infections are a major cause of morbidity in sexually active individuals worldwide, therefore, the World Health Organization has stated that sexually transmitted diseases (STDs) rank second in importance after cancer as treatable diseases in women. In particular,

\footnotetext{
* Correspondence: hiroyuki@med.hokudai.ac.jp

'Department of Medical Laboratory Science, Faculty of Health Sciences, Hokkaido University, Nishi-5 Kita-12 Jo, Kita-ku, Sapporo, Hokkaido 060-0812, Japan

Full list of author information is available at the end of the article
}

Chlamydia trachomatis is the leading cause of bacterial STD, with an estimated 5 million new cases annually worldwide [1-3]. C. trachomatis infection can cause testicular atrophy, epididymitis and orchitis in men, and ductal obstruction, pelvic inflammatory disease, tubal occlusion and extrauterine pregnancy in women [4-9]. However, the aetiology of most cases of chlamydial infection is undetermined and it could be multifactorial in nature, because of complications with commensal bacteria or mixed infections with other pathogens [10-12].

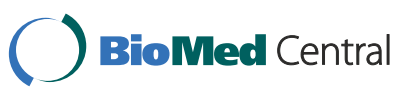


Therefore, the prevalence of C. trachomatis and other pathogens needs to be investigated.

Ureaplasma are currently separated into two species: Ureaplasma urealyticum and Ureaplasma parvum, which are both thought to be genital tract commensals [13-17]. They are commonly found in healthy persons, therefore, their pathogenic role can be difficult to prove in a small population of individuals. Meanwhile, several studies have reported that Ureaplasma are associated with some diseases including non-gonococcal urethritis, pregnancy complications and prenatal infections, more often than are normal flora [18-20]. Thus, it might be that Ureaplasma perturb homeostasis in the genital tract, which provides a survival advantage for $C$. trachomatis. However, data regarding mixed infection of C. trachomatis with Ureaplasma are limited [13-15].

In the present study, we therefore attempted to estimate by PCR and culture (C. trachomatis, inclusion forming assay; Ureaplasma, urease test), the prevalence of $C$. trachomatis, $U$. parvum and $U$. urealyticum in healthy women attending their first prenatal visit at a community hospital in Sapporo, Japan.

\section{Methods}

\section{Bacteria}

C. trachomatis D/UW3 Cx strain (VR-855) and $U$. parvum (ATCC-27813) were purchased from ATCC (Manassas, VA, USA). C. trachomatis and U. parvum were propagated in the HEp-2 cell culture system [21] and PPLO medium $[1.5 \%(\mathrm{w} / \mathrm{v})$ PPLO powder, $20 \%(\mathrm{v} / \mathrm{v})$ horse serum, $5 \%(\mathrm{w} / \mathrm{v})$ yeast extract, $1 \%(\mathrm{w} / \mathrm{v})$ urea, $0.1 \%(\mathrm{w} / \mathrm{v})$ phenol red, antibiotics $(10 \mu \mathrm{g} / \mathrm{ml}$ vancomycin; $1 \mu \mathrm{g} / \mathrm{ml}$ amphotericin B), $\mathrm{pH}$ 6.0], respectively. The numbers of infectious progenies for $C$. trachomatis were determined as inclusion forming units (IFU) by counting chlamydial inclusions formed in HEp-2 cells using fluorescein isothiocyanate (FITC)-conjugated monoclonal anti-Chlamydia antibody specific to Chlamydia lipopolysaccharide (LPS) (Denka Seiken Co. Ltd., Tokyo, Japan) [21]. The numbers U. parvum were also determined as colony-forming units (CFU) by counting colonies formed on the PPLO agar under a phase-contrast microscope.

\section{Endocervical samples}

Three hundred and three samples were obtained from apparently healthy women attending their first prenatal visit at Toho Obstetrics and Gynecology Hospital [number of deliveries, 1,332 per year (2010); number of caesarean sections, 310 per year (2010); number of vacuum extractions, 106 per year (2010)], located on the outskirts of Sapporo City, Japan, from July 2010 to September 2010. The average age $( \pm \mathrm{SD})$ of healthy women attending this hospital was $28.28 \pm 5.25$ years, and the age distribution was as follows: 94 (20-24 years), 93 (25-29 years), 59 (30-34 years), 25 (35-40 years), and nine ( $>40$ years). The samples were collected by scraping the endocervix of each woman with a sterile cotton applicator. The applicator was immediately immersed and resuspended in $1 \mathrm{ml}$ sucrose-phosphate-glutamic acid buffer [SPG: $0.2 \mathrm{M}$ sucrose, $3.8 \mathrm{mM} \mathrm{KH_{2 }} \mathrm{PO}_{4}, 6.7 \mathrm{mM} \mathrm{Na}_{2} \mathrm{HPO}_{4}, 5 \mathrm{mM}$ L-glutamic acid (pH 7.4)][21], and stored at $-80^{\circ} \mathrm{C}$ until use.

\section{Ethics}

Written informed consent was obtained from all women, and the study was approved by the ethics committees of the Faculty of Health Sciences, Hokkaido University and Toho Obstetrics and Gynecology Hospital.

\section{DNA extraction}

One hundred microlitres of SPG solution in each sample was used for DNA extraction using a QIAmp DNA mini kit (Qiagen, Valencia, CA, USA), according to manufacturer's instructions. The solution was centrifuged at $18,900 \times \mathrm{g}$ for $30 \mathrm{~min}$. Pellets were then used for DNA extraction. The DNA was eluted in $50 \mu \mathrm{l}$ of the elution buffer supplied with the kit, quantitated spectrophotometrically and stored at $-20^{\circ} \mathrm{C}$ until use.

\section{PCR detection and lineage analysis with ompA full sequences}

Table 1 shows primer sets and conditions for PCR amplification of C. trachomatis [22], U. parvum [13], U. urealyticum [13], and most bacteria [23]. The quality of extracted DNA was confirmed by PCR amplification using universal primers that target bacterial $16 \mathrm{~S} r R N A$, which is conserved across a broad spectrum of bacteria. DNA samples that resulted in negative PCR for bacterial $16 S$ rRNA were discarded. Finally, the samples $(n=280)$ that yielded PCR products of the expected size were used for PCR amplification of C. trachomatis (target gene, ompA) [22], U. parvum [target gene, 5 ' ends of the multiple-banded antigen gene (MBA) with upstream region] [13] and $U$. urealyticum (target gene, MBA with upstream region) [13]. Template DNA $(2 \mu \mathrm{l})$ (average amount of DNA per sample: $63.64 \pm 89.16 \mathrm{ng} / \mu \mathrm{l}$ ) was used for each PCR. Reactions were carried out in $25 \mu \mathrm{l}$ reaction buffer [each dNTP, 200 $\mu \mathrm{mol}$; $1 \times$ commercial reaction buffer (New England Biolabs, Herts, UK)] containing Taq DNA polymerase [0.625 U Taq DNA polymerase (New England Biolabs). The PCR cycle consisted of $10 \mathrm{~min}$ denaturation at $94^{\circ} \mathrm{C}$ followed by $30-45$ cycles, each of $30 \mathrm{~s}$ denaturation at $94^{\circ} \mathrm{C} ; 30 \mathrm{~s}$ of annealing at $52-58^{\circ} \mathrm{C}$; and $45 \mathrm{~s}$ of extension at $72^{\circ} \mathrm{C}$. The amplified products were separated by $1.2 \%$ agarose gel electrophoresis and visualized by ethidium bromide staining. Each PCR was performed at least two times, for confirmation of PCR specificity and reproducibility. In addition, to prevent contamination, the preparation of the 
Table 1 Primer sequences and PCR conditions used for this study

\begin{tabular}{|c|c|c|c|c|c|c|}
\hline \multirow[t]{2}{*}{ Microorganism } & \multirow[t]{2}{*}{ Target gene } & \multirow[t]{2}{*}{ Primer } & \multirow[t]{2}{*}{ Sequence } & \multirow{2}{*}{$\begin{array}{l}\text { Annealing } \\
\text { condition; } \\
\text { Temperature/ } \\
\text { cycle }\end{array}$} & \multirow{2}{*}{$\begin{array}{l}\text { Expected } \\
\text { fragment } \\
\text { size }\end{array}$} & \multirow[t]{2}{*}{$\begin{array}{l}\text { Reference [Reference } \\
\text { number] }\end{array}$} \\
\hline & & & & & & \\
\hline \multirow[t]{2}{*}{ Most bacteria } & $16 S$ rRNA & $\begin{array}{l}\text { Forward } \\
\text { (Bac3) }\end{array}$ & $\begin{array}{l}\text { 5'-AGA GTT TGA TYM TGG CTC } \\
\text { AG-3** }\end{array}$ & $52 / 35$ & $\begin{array}{l}\text { nearly full- } \\
\text { length }\end{array}$ & Horn et al., 1999 [22] \\
\hline & & $\begin{array}{l}\text { Reverse } \\
\text { (Bac4) }\end{array}$ & $5^{\prime}-$ CAK AAA GGA GGT CC-3*** & & & \\
\hline \multirow[t]{2}{*}{$\begin{array}{l}\text { Chlamydia } \\
\text { trachomatis }\end{array}$} & ompA & $\begin{array}{l}\text { Forward } \\
\text { (CtOmp1) } \\
\end{array}$ & $\begin{array}{l}\text { 5'-ATG AAA AAA CTC TTG AAA } \\
\text { TCG G-3' }\end{array}$ & $55 / 35$ & $1,100 \mathrm{bp}$ & $\begin{array}{l}\text { Jurstrand et al., } 2010 \\
\text { [23] }\end{array}$ \\
\hline & & $\begin{array}{l}\text { Reverse } \\
\text { (CtOmp2) }\end{array}$ & $\begin{array}{l}\text { 5'ACT GTA ACT GCG TAT TTG } \\
\text { TCT G-3' }\end{array}$ & & & \\
\hline \multirow[t]{2}{*}{$\begin{array}{l}\text { Ureaplasma } \\
\text { parvum }\end{array}$} & MBA gene with & $\begin{array}{l}\text { Forward } \\
\text { (UMS-57) }\end{array}$ & $\begin{array}{l}5^{\prime}-(T / C) A A \text { ATC TTA GTG TTC ATA } \\
\text { TाT TाT AC-3' }\end{array}$ & $58 / 35$ & $326 / 327 \mathrm{bp}$ & Kong et al., 2000 [13] \\
\hline & it upstream region*** & $\begin{array}{l}\text { Reverse } \\
\text { (UMA222) }\end{array}$ & $\begin{array}{l}\text { 5'-GTA AGT GCA GCA TTA AAT } \\
\text { TCA ATG-3' }\end{array}$ & & & \\
\hline \multirow[t]{2}{*}{$\begin{array}{l}\text { Ureaplasma } \\
\text { urealyticum }\end{array}$} & $\begin{array}{l}\text { MBA gene with it } \\
\text { upstream region }\end{array}$ & $\begin{array}{l}\text { Forward } \\
\text { (UMS-170) }\end{array}$ & $\begin{array}{l}\text { 5'-GTA TाT GCA ATC TाT ATA } \\
\text { TGT TाT CG-3' }\end{array}$ & $58 / 45$ & $476 \mathrm{bp}$ & Kong et al., 2000 [13] \\
\hline & & $\begin{array}{l}\text { Reverse } \\
\text { (UMA263) }\end{array}$ & 5'-TTT GTT GTT GCG TाT TCT-3' & & & \\
\hline
\end{tabular}

*Y, $C$ or $\mathrm{T} ; \mathrm{M}, \mathrm{A}$ or $\mathrm{C}$

** $\mathrm{K}, \mathrm{G}$ or $\mathrm{T}$

${ }^{* * *} \mathrm{MBA}, 5^{\prime}$ ends of the multiple-banded antigen gene

PCR mixture was performed in a separate room. All products of ompA amplified in C. trachomatis-positive specimens were fully sequenced (Macrogen, Seoul, Korea) and each of the genotypes was determined through BLAST search. Lineage analysis with ompA sequences was also performed by the following method: C. trachomatis ompA sequences were aligned with MUSCLE software [23]. Then, the phylogenetic tree was constructed using the neighbour-joining method with MEGA5 software [24]. The following reference sequences were used: A/Sa1 (M58938), B/TW-5 (M17342), C/TW3 (M17343), D/B-120 (X62918), E/Bour (X52557), F/IC-Cal3 (X52080), G/UW57 (AF063199), H/Wash (X16007), I/UW-12 (AF063200), J/ UW36 (AF063202), K/UW31 (AF063204), L1/440 (M36533), L2/434 (M14738), and L3/404 (X55700). Chlamydia muridarum MoPn (M64171) was also used as an out-group sequence. The gene accession numbers of sequences identified in this study were deposited in "DNA Data Bank of Japan" and available from authors upon request.

\section{PCR detection limit for $C$. trachomatis and ureaplasmas}

To determine the detection limit of PCR for C. trachomatis and Ureaplasma spp., spike experiments were performed. $U$. parvum was used as a representative Ureaplasma. Several sets of $100 \mu \mathrm{l}$ of SPG solution in the pooled swab samples, which proved negative for $C$. trachomatis and Ureaplasma, were prepared. The sets were spiked with serial dilutions of either $C$. trachomatis VR-855 from $10^{-2}$ to $10^{4} \mathrm{IFU}$ or $U$. parvum ATCC-27813 from $10^{-1}$ to $10^{5}$
CFU per sample. The DNA extraction of spiked samples, as well as from clinical specimen, was used for the PCRdetection method with primer sets targeting to C. trachomatis ompA and Ureaplasma MBA as described above.

\section{Biological detections}

The presence of infectious C. trachomatis in the samples confirmed as C. trachomatis-PCR positive was determined by inclusion formation assay on HEp- 2 cells. The presence of viable Ureaplasma in the samples confirmed as either $U$. parvum or $U$. urealyticum PCR-positive was also determined using a urease assay as follows. In brief, a sample solution of $5 \mu \mathrm{l}$ was diluted to $100 \mu \mathrm{l}$ with SPG, and then passed through a filter with a $0.22-\mu \mathrm{m}$ pore size. The filtrate was cultured in a total of $200 \mu \mathrm{l}$ of PPLO medium at $37^{\circ} \mathrm{C}$ for 7 days. Samples that turned from yellow to red after the incubation were considered Ureaplasma positive.

\section{Statistical analysis}

Comparison between the frequency of $C$. trachomatis and that of $U$. parvum or $U$. urealyticum was done by Fisher's exact test (two-way ANOVA; Statview, Abacus Concepts Inc., Piscatway, NJ, USA). A $p$ value $<0.05$ was considered significant.

\section{Results and discussion}

\section{Quality control of DNA extracted from endocervical} samples

We assessed by PCR amplification the bacterial flora in the genital tract, to confirm whether extracted DNA was 
suitable for PCR amplification that target C. trachomatis or Ureaplasma spp. Three hundred and three samples were individually assessed by PCR with a primer set targeting bacterial $16 S \mathrm{rRNA}$. The average amount of DNA was $63.64 \pm 89.16 \mathrm{ng} / \mu \mathrm{l}$, which indicated successful DNA extraction, therefore, it was expected that all samples would be available for PCR. However, in 23 samples (9.2\%) PCR failed to amplify $16 \mathrm{~S}$ rRNA gene, even though the amount of extracted DNA was never low. Therefore, the 23 samples without amplification were omitted and the remaining 280 were used for this study. Standard PCR techniques, which can be applied to analyse the entire microorganism community of complex biological samples obtained from living individuals, has been universally used. However, it is well known that haemoglobin, lactoferrin, heparin, and bile acids, which are ubiquitous to environments such as the genital tract, inhibit PCR amplification [25]. This suggests that it is absolutely necessary to check the DNA quality carefully to confirm successful PCR amplification from genital swab samples.

PCR detection of C. trachomatis, U. parvum and $U$. urealyticum

The detection limit of the PCR for either C. trachomatis ompA or Ureaplasma MBA with upstream region was examined by using DNAs extracted from the pooled genital swabs [confirmed that all targeted bacteria $(C$. trachomatis and Ureaplasma spp.) were negative] that had been spiked with defined numbers of either C. trachomatis or $U$. parvum. The detection limit of the PCR in spiked genital swabs for $C$. trachomatis and $U$. parvum (as a representative Ureaplasma) was 1 IFU and $100 \mathrm{CFU}$ per $100 \mu \mathrm{l}$ of swab sample, respectively. The spiked samples revealed that the PCR system allowed stable and sensitive detection of each target DNA. Although the PCR primers that targeted C. trachomatis ompA for C. trachomatis detection were used for this study, it has also been shown worldwide that cryptic plasmid gene permits detection of C. trachomatis from clinical specimens [26-28]. However, so far it has also been reported that there is absence, variation or deletion of the plasmid in C. trachomatis [29-31], in particular, causing a clinical problem with false-negative results for C. trachomatis in Europe [29-31]. Although plasmid copy number is generally much higher than that of a genomic gene, which increases the sensitivity of PCR detection, we did not use cryptic plasmid for PCR targeting of $C$. trachomatis detection to prevent false-negative results. Detection of $U$. parvum and $U$. urealyticum with PCR primers targeting MBA genes with variable regions has been well documented for Ureaplasma detection [13,32-36] therefore, we selected this gene for PCR detection of Ureaplasma spp. In fact, as shown in
Figure 1 (representative PCR results), each of the PCR products was clearly visible, permitting us to make accurate judgements.

\section{Prevalence of C. trachomatis, $U$. parvum and $U$. urealyticum}

As shown in Figure 2, PCR detection revealed that the prevalence of $C$. trachomatis, $U$. parvum and $U$. urealyticum was $14.3 \%, 41.7 \%$ and $8.9 \%$, respectively. The prevalence of C. trachomatis in healthy women has been estimated worldwide. The detection frequency among healthy women varies between countries and cities (46\% Colombia [37]; 22.9\% England [38]; 3.9\% USA (Baltimore) [39]; 0.2\% Australia [40]), probably depending on prevailing environmental factors and population living habits. However, its infectious frequency is believed to be around $10 \%$ on an average from a global perspective [1,2]. As compared to other studies with healthy women in Japan ( $~ 5.8 \%$ on average; $3.0-3.8 \%$ Tokyo [39,41]; 5.6\% Fukuoka [42]; 8.3-8.8\% Miyasaki [43,44]; 1.7\% Nasushiobara [45]; 9.5\% Wako [46]), the prevalence of C. trachomatis in Sapporo City that we estimated (14.3\%) was unique. Our result is supported by a previous study showing a $C$. trachomatis detection frequency of $11.3 \%$ in Sapporo [47]. Thus, the prevalence of C. trachomatis in Sapporo, Japan, is likely to be high. Although we cannot explain the exact reason for this high prevalence, it may be related to the fact that the city has a relatively large population ( $\sim 2$ million) with an active nightlife, (Susukino district, $\sim 3.7 \mathrm{~km}$ from the hospital), which particularly attracts sexually active young people.

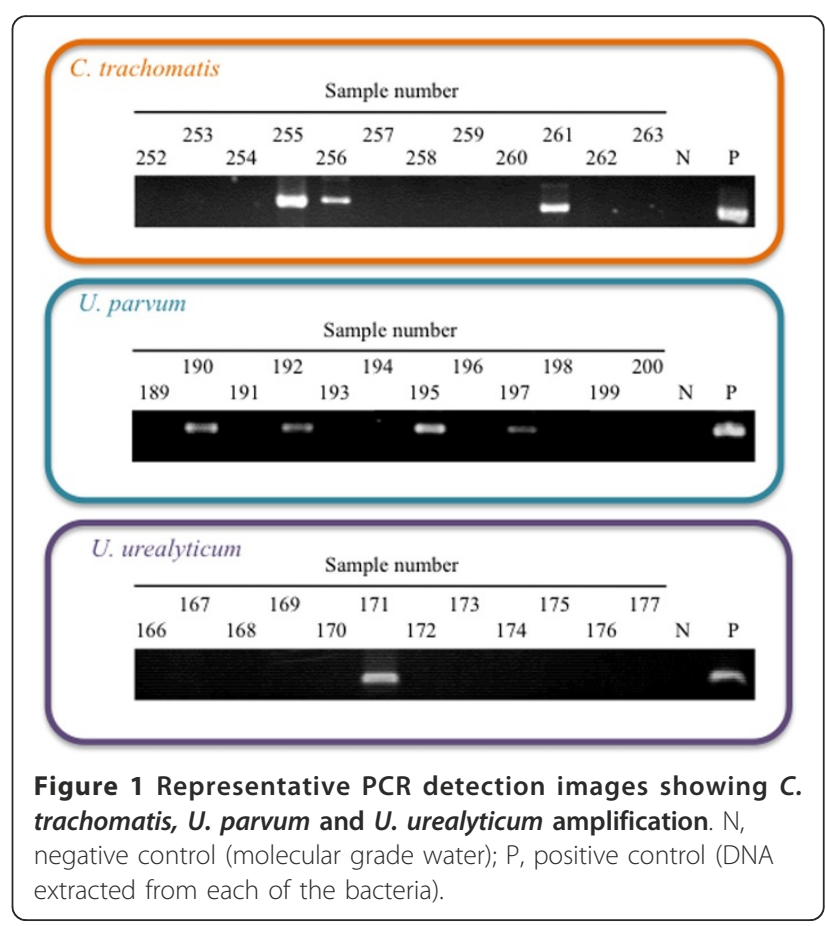




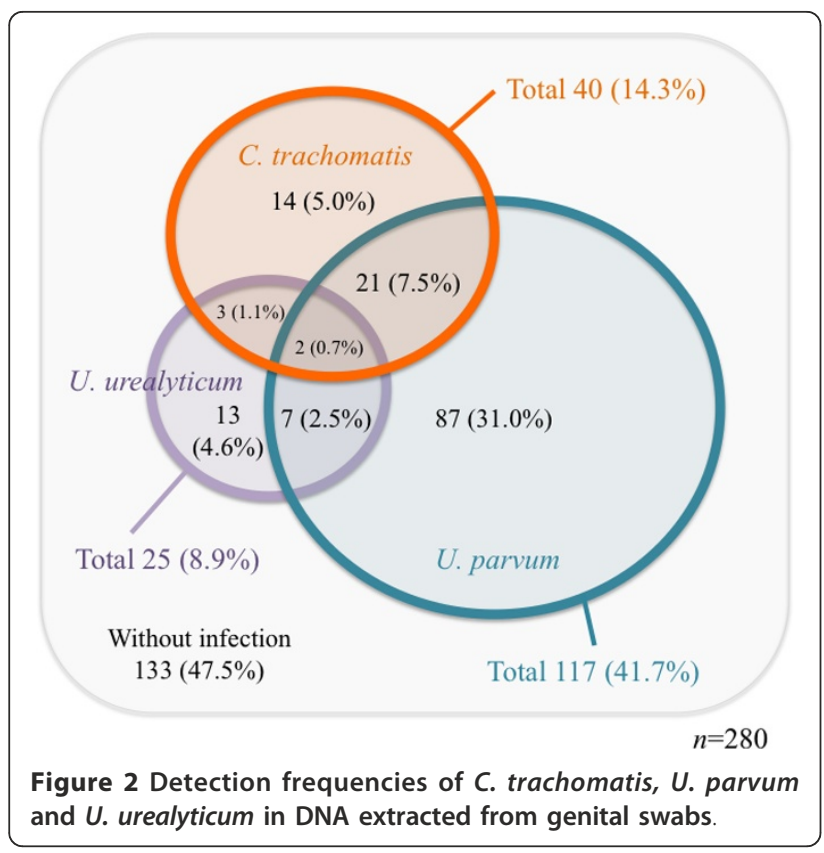

We also found that the detection frequency in the youngest age group (20-24 years), who were more sexually active, predictably increased from $14.3 \%$ to $23.4 \%$.

PCR detection also revealed that the prevalence of $U$. parvum and $U$. urealyticum was $41.7 \%$ and $8.9 \%$, respectively. Other studies with healthy women also have reported that the detection frequency of $U$. parvum and $U$. urealyticum was estimated at $\sim 50 \%$ (57 and $87 \%$ Australia [13,48]; 52\% Japan [49]; 33.2 and 86.8\% China [50]; $86 \%$ Italy [51]; $17.9 \%$ Poland [52]) and 10\% (6.1-19\% Australia [13]; 8.7\% Japan [49]; 4.6-10.5\% China [50]; 14\% Italy [51]; 2.6\% Poland [52]). The findings with our data suggested that the distribution of Ureaplasma is spreading worldwide and that the species are commonly found in healthy people as presumably commensal bacteria, therefore, their pathogenic role would be minimal [53-56]. Nevertheless, it has been increasingly reported that Ureaplasma spp. are associated with non-gonococcal urethritis, chorioamnionitis, preterm birth, perinatal morbidity, and mortality, more often than are normal flora [53-55]. Thus, our knowledge regarding the pathogenesis of Ureaplasma still remains paradoxical and is limited, suggesting that further, larger epidemiological studies with healthy people and patients with urogenital disorders are needed.

The gold standard for bacterial detection from clinical specimens is probably culture; therefore, we also assessed whether C. trachomatis and Ureaplasma spp. in PCR-positive samples could be detected by using biological detection systems, IFU assay and urease assay, respectively. However, contrary to our expectation, the detection frequencies of C. trachomatis and Ureaplasma spp. in PCR-positive samples decreased to $30 \%$ and $2 \%$, respectively. Although it is necessary to clarify the exact reason, it is possible that freeze-thawing of samples crucially caused a decrease in detection frequencies.

\section{Mixed infection of $C$. trachomatis and Ureaplasma}

Surprisingly, either C. trachomatis or Ureaplasma spp. was detected in almost half of the healthy women $(52.5 \%$, 147/280), and mixed infection with C. trachomatis and either $U$. parvum or $U$. urealyticum was observed in $9.2 \%$ $(26 / 280)$ (Figure 2, See overlapping area). It is intriguing that there was a significant association between $C$. trachomatis and either U. parvum ( $p=0.023)$ or Ureaplasma total $(p=0.013)$, but not $U$. urealyticum $(p=0.275)$ (Table 2). Meanwhile, several studies also estimated the mixed infection frequency; however, correlation between the frequency of $C$. trachomatis and either $U$. parvum or $U$. urealyticum was limited, and has been considered less serious in urogenital infections [56-58]. At present, we do not have any explanation to resolve this contradiction. It is possibly due to the particular experimental design, including detection methods such as PCR or serology, or a lack of accurate quality control for DNA extraction. Our study revealed that $U$. parvum had a significant effect on the presence of C. trachomatis in the genital tract of healthy women, suggesting that mixed infection is an important factor in bacterial pathogenesis of the genital tract. Meanwhile, whether this observation is limited to Sapporo City remains unknown. In addition, there was no difference of C. trachomatis frequency between $U$. parvum [20\% (23/ $117)]$ and $U$. urealyticum $[20 \%(5 / 25)]$ positive samples. This implies that $U$. urealyticum also may have a potential effect on the presence of $C$. trachomatis as well as U. parvum.

As shown in Figure 3, we also estimated the frequency of ompA genotypes among $C$. trachomatis that we detected by direct full sequencing $(n=40)$. As a result, we finally determined the following $C$. trachomatis ompA genotypes: D (30\%), B (2.5\%), E (7.5\%), F (12.5\%), G (0.5\%), I (12.5\%), J (5\%), K (10\%), and undetermined (17.5\%). Although C. trachomatis ompA genotype D was the most frequently identified, there was no association of the genotype with either $U$. parvum or $U$. urealyticum.

Why does $C$. trachomatis co-infect with $U$. parvum in the genital tract? So far, we do not have any definite explanation. However, it is possible that the presence of $U$. parvum could provide some advantages for survival of C. trachomatis in the genital tract, possibly through directly or indirectly supplying tryptophan to overcome the depletion of this amino acid inside the cells by interferon $\gamma$ exposure $[59,60]$.

\section{Conclusion}

Endocervical samples were taken from 303 women attending their first prenatal visit at a community 
Table 2 Correlation between prevalence of $C$. trachomatis and ureaplasmas in the genital swabs

\begin{tabular}{|c|c|c|c|c|c|c|c|c|c|}
\hline \multirow[t]{2}{*}{ Result for C. trachomatis DNA (n) } & \multicolumn{2}{|c|}{$\begin{array}{l}\text { No. (\%) of samples for } U \text {. } \\
\text { parvum DNA testing }\end{array}$} & \multirow[t]{2}{*}{$p^{*}$} & \multicolumn{2}{|c|}{$\begin{array}{l}\text { No. (\%) of samples for } U \text {. } \\
\text { urealyticum DNA testing }\end{array}$} & \multirow[t]{2}{*}{$p$} & \multicolumn{2}{|c|}{$\begin{array}{l}\text { No. (\%) of samples for } \\
\text { Ureaplasma total DNA testing }\end{array}$} & \multirow[t]{2}{*}{$p$} \\
\hline & Positive & Negative & & Positive & Negative & & Positive & Negative & \\
\hline Positive (40) & $23(57.5)$ & $17(42.5)$ & 0.02 & $5(12.5)$ & $35(87.5)$ & 0.28 & $26(65)$ & $14(35)$ & 0.01 \\
\hline Negative (240) & $94(32.5)$ & $146(53.5)$ & & $20(8.3)$ & $220(91.7)$ & & 107 (44.6) & $133(55.4)$ & \\
\hline
\end{tabular}

${ }^{*}$ Correlation between these frequencies was analyzed by Fisher's exact test

hospital in Sapporo, Japan, and the extracted DNAs $(n=$ 280), amenable to $16 S$ rRNA PCR amplification, were analysed by PCR that targeted C. trachomatis, $U$. parvum and $U$. urealyticum. The prevalence of C. trachomatis, $U$. parvum and $U$. urealyticum was $14.3 \%, 41.7 \%$

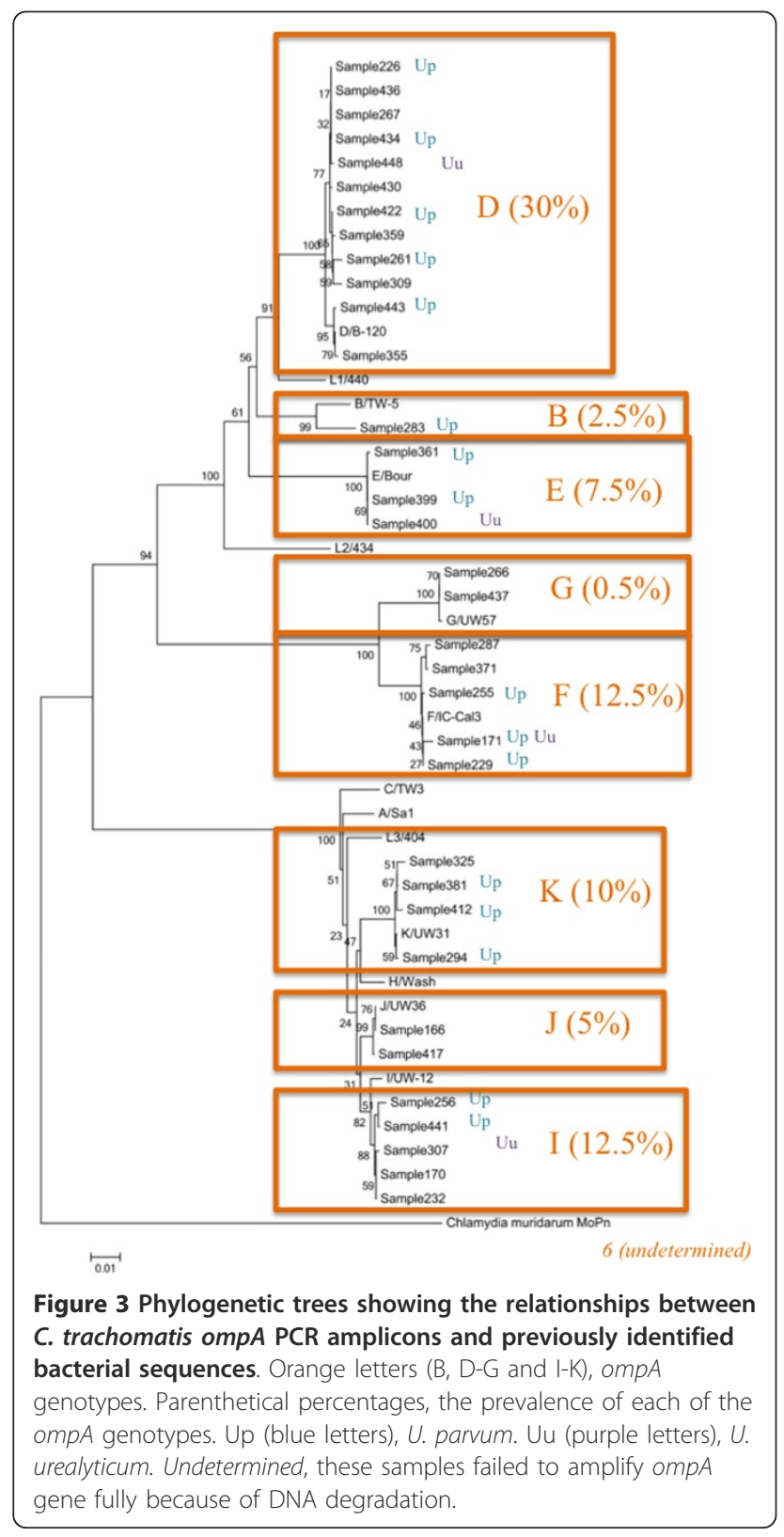

and $8.9 \%$, respectively. Mixed infection with C. trachomatis with either $U$. parvum or $U$. urealyticum was observed in $9.2 \%$ of the study population. Interestingly, there was a statistical correlation between the frequency of $C$. trachomatis and either $U$. parvum $(p=0.023)$ or Ureaplasma total $(p=0.013)$, but not $U$. urealyticum $(p=0.275)$. Thus, this study demonstrated that the presence of Ureaplasma had a significant effect on the presence of $C$. trachomatis in the genital tract of healthy women.

\section{Acknowledgements}

We thank the staff at the Department of Medical Laboratory Science, Faculty of Health Sciences, Hokkaido University, for their assistance throughout this study. This study was supported in part by grants-in-aid for scientific research (21590474), and a research grant from the Institute for Fermentation, Osaka, Japan.

\section{Author details}

'Department of Medical Laboratory Science, Faculty of Health Sciences, Hokkaido University, Nishi-5 Kita-12 Jo, Kita-ku, Sapporo, Hokkaido 060-0812, Japan. ${ }^{2}$ Toho Obstetrics and Gynecology Hospital, Higashi-15, Kita-17 Jo, Higashi-ku, Sapporo 065-0017, Japan.

\section{Authors' contributions}

TY and MM performed the DNA extraction and the PCR. TY and MM performed the biological detection. TY performed the purification of PCR products for DNA sequencing. MM and $\mathrm{HY}$ validated the statistical analysis. HY designed this study. KA and KM performed the sample collection. JM and $\mathrm{HY}$ supervised the practical work and the data management. HY wrote the manuscript. All authors approved the final manuscript version.

\section{Competing interests}

The authors declare that they have no competing interests.

Received: 31 January 2012 Accepted: 2 April 2012

Published: 2 April 2012

\section{References}

1. WHO: Global Prevalence and incidence of Curable Stis Geneva: World Health Organization; 2001.

2. WHO: Priority eye diseases 2008, [WWW document]. URL http://www.who. int/blindness/causes/priority/en/index2.html.

3. Horner P: The case for further treatment studies of uncomplicated genital Chlamydia trachomatis infection. Sex Transm Infect 2006, 82:340-343.

4. Gallegos G, Ramos B, Santiso R, Goyanes V, Gosalvez J, Fernandez UL: Sperm DNA fragmentation in infertile men with genitourinary infection by Chlamydia trachomatis and Mycoplasma. Fertil Steril 2008, 90:328-334.

5. Bezold G, Politch JA, Kiviat NB, Kuypersm JM, Wolff H, Anderson DJ: Prevalence of sexually transmissible pathogens in semen from asymptomatic male infertility patients with and without leukocytospermia. Fertil Steril 2007, 87:1087-1097.

6. Jakiel G, Robak-Cholubek D, Wieczorek P, Bokiniec M: Evaluation of some parameters of human semen with positive chlamydial reaction. Ann Univ Mariae Curie Sklodowska 2004, 59:61-64. 
7. Gdoura R, Keskes-Ammar L, Bouzid F, Eb F, Hammami A, Orfila J: Chlamydia trachomatis and male infertility in Tunisia. Eur J Contracept Reprod Health Care 2001, 6:102-107.

8. Custo GM, Lauro V, Saitto C, Frongillo RF: Chlamydial infection and male infertility: an epidemiological study. Arch Androl 1989, 23:243-248.

9. Gump D, Gibson M, Ashikaga T: Evidence of prior pelvic inflammatory disease and its relationship to Chlamydia trachomatis antibody and intrauterine contraceptive device use in infertile women. Am J Obstet Gynecol 1983, 146:153-159.

10. Lusk MJ, Konecny P: Cervicitis: a review. Curr Opin Infect Dis 2008, 21:49-55.

11. Marrazzo JM: Mucopurulent cervicitis: no longer ignored, but still misunderstood. Infect Dis Clin N America 2005, 19:333-349.

12. Debattista J, Gazzard CM, Wood RN, Allan JA, Allan JM, Scarman A, Mortlock M, Timms P, Knox CL: Interaction of microbiology and pathology in women undergoing investigations for infertility. Infect Dis Obstet Gynecol 2004, 12:135-145.

13. Kong F, Ma Z, James G, Gordon S, Gilbert GL: Species identification and subtyping of Ureaplasma parvum and Ureaplasma urealyticum using PCR-based assays. J Clin Microbiol 2000, 38:1175-1179.

14. Kong F, James G, Ma Z, Gordon S, Wang B, Gilbert GL: Phylogenetic analysis of Ureaplasma urealyticum-support for the establishment of a new species, Ureaplasma parvum. Int J Syst Bacteriol 1999, 49:1879-1889.

15. Kong F, Zhu X, Wang W, Zhou X, Gordon S, Gilbert GL: Comparative analysis and serovar-specific identification of multiple-banded antigen genes of Ureaplasma urealyticum biovar 1. J Clin Microbiol 1999, 37:538-543.

16. Abele-Horn M, Wolff C, Dressel P, Pfaff F, Zimmermann A: Association of Ureaplasma urealyticum biovars with clinical outcome for neonates, obstetric patients, and gynecological patients with pelvic inflammatory disease. J Clin Microbiol 1997, 35:1199-1202

17. Taylor-Robinson D, Furr PM: Genital Mycoplasma infections. Wien Klin Wochenschr 1997, 109:578-583.

18. Ollikainen J, Heiskanen-Kosma T, Korppi M, Katila ML, Heinonen K: Clinical relevance of Ureaplasma urealyticum colonization in preterm infants. Acta Paediatr 1998, 87:1075-1078.

19. Tully JG: Current status of the mollicute flora of humans. Clin Infect Dis 1993, 17(Suppl 1):S2-S9.

20. Zheng X, Watson HL, Waites KB, Cassell GH: Serotype diversity and antigen variation among invasive isolates of Ureaplasma urealyticum from neonates. Infect Immun 1992, 60:3472-3474.

21. Kobayashi M, Ishida K, Matsuo J, Nakamura S, Nagasawa A, Motohashi K, Yao T, Hirai I, Yamamoto Y, Suzuki H, Shimizu C, Matsuno K, Yamaguchi H: Chlamydophila pneumoniae attachment and infection in low proteoglycan expressing human lymphoid Jurkat cells. Microb Pathog 2011, 51:209-216.

22. Edgar RC: MUSCLE: multiple sequence alignment with high accuracy and high throughput. Nucleic Acids Res 2004, 32:1792-1797.

23. Mahony JB, Jang D, Chong S, Luinstra K, Sellors J, Tyndall M, Chernesky M: Detection of Chlamydia trachomatis, Neisseria gonorrhoeae, Ureaplasma urealyticum, and Mycoplasma genitalium in first-void urine specimens by multiplex polymerase chain reaction. Mol Diagn 1997, 2:161-168.

24. Jurstrand $M$, Christerson $L$, Klint $M$, Fredlund $H$, Unemo $M$, Herrmann $B$ : Characterisation of Chlamydia trachomatis by ompA sequencing and multilocus sequence typing in a Swedish county before and after identification of the new variant. Sex Transm Infect 2010, 86:56-60.

25. Horn M, Fritsche TR, Gauton RK, Schleifer KH, Wagner M: Novel bacterial endosymbionts of Acanthamoeba spp. related to the Paramecium caudatum symbiont Caedibacter caryohilus. Environ Microbiol 1999 1:357-367

26. Wilson IG: Inhibition and facilitation of nucleic acid amplification. App/ Environ Microbiol 1997, 63:3741-3751.

27. Magbanua JP, Goh BT, Michel CE, Aguirre-Andreasen A, Alexander S, UshiroLumb I, Ison C, Lee H: Chlamydia trachomatis variant not detected by plasmid based nucleic acid amplification tests: molecular characterisation and failure of single dose azithromycin. Sex Transm Infect 2007, 83:339-343.

28. Skulnick M, Chua R, Simor AE, Low DE, Khosid HE, Fraser S, Lyons E, Legere EA, Kitching DA: Use of the polymerase chain reaction for the detection of Chlamydia trachomatis from endocervical and urine specimens in an asymptomatic low-prevalence population of women. Diagn Microbiol Infect Dis 1994, 20:195-201.
29. Jurstrand M, Olcén P, Magnuson A, Jakobsson L, Fredlund H, Unemo M: Emergence of the new variant of Chlamydia trachomatis in a defined area of Sweden before 2002? Sex Transm Infect 2010, 86:337-341.

30. Ripa T, Nilsson PA: A Chlamydia trachomatis strain with a 377-bp deletion in the cryptic plasmid causing false-negative nucleic acid amplification tests. Sex Transm Dis 2007, 34:255-256.

31. Stevens MP, Tan SE, Horvath L, Fairley CK, Garland SM, Tabrizi SN: Absence of a Chlamydia trachomatis variant, harbouring a deletion in the cryptic plasmid, in clients of a sexually transmissible infection clinic and antenatal patients in Melbourne. Commun Dis Intell 2008, 32:77-81.

32. Kong F, Gilbert GL: Postgenomic taxonomy of human ureaplasmas - a case study based on multiple gene sequences. Int I Syst Evol Microbiol 2004, 54:1815-1821.

33. Monecke S, Helbig JH, Jacobs E: Phase variation of the multiple banded protein in Ureaplasma urealyticum and Ureaplasma parvum. Int J Med Microbiol 2003, 293:203-211.

34. Zimmerman CU, Stiedl T, Rosengarten R, Spergser J: Alternate phase variation in expression of two major surface membrane proteins (MBA and UU376) of Ureaplasma parvum serovar 3. FEMS Microbiol Lett 2009, 292:187-193.

35. Teng LJ, Ho SW, Ho HN, Liaw SJ, Lai HC, Luh KT: Rapid detection and biovar differentiation of Ureaplasma urealyticum in clinical specimens by PCR. J Form Med Assoc 1995, 94:396-400.

36. Teng LJ, Zheng X, Glass JI, Watson HL, Tsai J, Cassell GH: Ureaplasma urealyticum biovar specificity and diversity are encoded in multiplebanded antigen gene. J Clin Microbiol 1994, 32:1464-1469.

37. Molano M, Meijer CJ, Weiderpass E, Arslan A, Posso H, Franceschi S, Ronderos M, Muñoz N, van den Brule AJV: The natural course of Chlamydia trachomatis infection in asymptomatic Colombian women: a 5-year follow-up study. J Infect Dis 2005, 191:907-916.

38. Scott Lamontagne D, Baster K, Emmett L, Nichols T, Randall S, McLean L, Meredith P, Harindra V, Tobin JM, Underhill GS, Graham Hewitt W, Hopwood J, Gleave T, Ghosh AK, Mallinson H, Davies AR, Hughes G, Fenton KA: Incidence and reinfection rates of genital chlamydial infection among women aged 16-24 years attending general practice, family planning and genitourinary medicine clinics in England: a prospective cohort study by the chlamydia recall study advisory group Sex Transm Infect 2007, 2007(83):292-303.

39. Eggleston E, Rogers SM, Turner CF, Miller WC, Roman AM, Hobbs MM, Erbelding E, Tan S, Villarroel MA, Ganapathi L: Chlamydia trachomatis infection among 15- to 35-year-olds in Baltimore, MD. Sex Transm Dis 2011, 38:743-749.

40. Regan DG, Wilson DP, Hocking JS: Coverage is the key for effective screening of Chlamydia trachomatis in Australia. J Infect Dis 2008, 198:349-358.

41. Ishi K, Suzuki F, Saito A, Kubota T: Prevalence of human papillomavirus, Chlamydia trachomatis, and Neisseria gonorrhoeae in commercial sex workers in Japan. Infect Dis Obstet Gynecol 2000, 8:235-239.

42. Tsunoe H, Tanaka M, Nakayama H, Sano M, Nakamura G, Shin T, Kanayama A, Kobayashi I, Mochida O, Kumazawa J, Naito S: High prevalence of chlamydia trachomatis, neisseria gonorrhoeae and mycoplasma genitalium in female commercial sex workers in Japan. Int J STD AIDS 2000, 11:790-794.

43. Imai $H$, Shinohara $H$, Nakao $H$, Tsukino $H$, Hamasuna $R$, Katoh T: Prevalence and risk factors of asymptomatic chlamydial infection among students in Japan. Int J STD AIDS 2004, 15:408-414.

44. Hamasuna R, Imai H, Tsukino $H$, Jensen JS, Osada Y: Prevalence of Mycoplasma genitalium among female students in vocational schools in Japan. Sex Transm Infect 2008, 84:303-305.

45. Yamada T, Atsuki Y, Wakasaya A, Kobayashi M, Hirano Y, Ohwada M: Characteristics of patients with subchorionic hematomas in the second trimester. J Obstet Gynaecol Res 2012, 38:180-184.

46. Imai $H$, Nakao $H$, Shinohara $H$, Fujii $Y$, Tsukino $H$, Hamasuna $R$, Osada $Y$, Fukushima K, Inamori M, Ikenoue T, Katoh T: Population-based study of asymptomatic infection with Chlamydia trachomatis among female and male students. Int J STD AIDS 2010, 21:362-366.

47. Ikehata M, Numazaki K, Chiba S: Analysis of Chlamydia trachomatis serovars in endocervical specimens derived from pregnant Japanese women. FEMS Immunol Med Microbiol 2000, 27:35-41

48. De Francesco MA, Negrini R, Pinsi G, Peroni L, Manca N: Detection of Ureaplasma biovars and polymerase chain reaction-based subtyping of 
Ureaplasma parvum in women with or without symptoms of genital infections. Eur J Clin Microbiol Infect Dis 2009, 28:641-646.

49. Mclver CJ, Rismanto N, Smith C, Naing ZW, Rayner B, Lusk MJ, Konecny P, White PA, Rawlinson WD: Multiplex PCR testing detection of higher-thanexpected rates of cervical mycoplasma, ureaplasma, and trichomonas and viral agent infections in sexually active australian women. J Clin Microbiol 2009, 47:1358-1363.

50. Kataoka S, Yamada T, Chou K, Nishida R, Morikawa M, Minami M, Yamada H, Sakuragi N, Minakami H: Association between preterm birth and vaginal colonization by mycoplasmas in early pregnancy. J Clin Microbiol 2006, 44:51-55.

51. Cao X, Wang Y, Hu X, Qing H, Wang H: Real-time TaqMan polymerase chain reaction assays for quantitative detection and differentiation of Ureaplasma urealyticum and Ureaplasma parvum. Diagn Microbiol Infect Dis 2007, 57:373-378.

52. Ekiel AM, Friedek DA, Romanik MK, Jóźwiak J, Martirosian G: Occurrence of Ureaplasma parvum and Ureaplasma urealyticum in women with cervical dysplasia in Katowice, Poland. J Korean Med Sci 2009, 24:1177-1181.

53. Grześko J, Elias M, Manowiec M, Gabryś MS: Genital mycoplasmasmorbidity and a potential influence on human fertility. Med Wieku Rozwoj 2006, 10:985-992.

54. Viscardi RM: Ureaplasma species: role in diseases of prematurity. Clin Perinatol 2010, 37:393-409.

55. Hartmann M: Genital mycoplasmas. J Dtsch Dermatol Ges 2009, 7:371-377.

56. Denks K, Spaeth EL, Jõers K, Randoja R, Talpsep T, Ustav M, Kurg R: Coinfection of Chlamydia trachomatis, Ureaplasma urealyticum and human papillomavirus among patients attending STD clinics in Estonia. Scand J Infect Dis 2007, 39:714-718.

57. Horner P, Thomas B, Gilroy CB, Egger M, Taylor-Robinson D: Role of Mycoplasma genitalium and Ureaplasma urealyticum in acute and chronic nongonococcal urethritis. Clin Infect Dis 2001, 32:995-1003.

58. Yokoi S, Maeda S, Kubota Y, Tamaki M, Mizutani K, Yasuda M, Ito S, Nakano M, Ehara H, Deguchi T: The role of Mycoplasma genitalium and Ureaplasma urealyticum biovar 2 in postgonococcal urethritis. Clin Infect Dis 2007, 45:866-871.

59. Nelson DE, Virok DP, Wood H, Roshick C, Johnson RM, Whitmire WM, Crane DD, Steele-Mortimer O, Kari L, McClarty G, Caldwell HD: Chlamydial IFN-gamma immune evasion is linked to host infection tropism. Proc Natl Acad Sci USA 2005, 102:10658-10663.

60. Morrison RP: New insights into a persistent problem - chlamydial infections. J Clin Invest 2003, 111:1647-1649.

\section{Pre-publication history}

The pre-publication history for this paper can be accessed here: http://www.biomedcentral.com/1471-2334/12/82/prepub

doi:10.1186/1471-2334-12-82

Cite this article as: Yamazaki et al:: Frequency of Chlamydia trachomatis in Ureaplasma-positive healthy women attending their first prenatal visit in a community hospital in Sapporo, Japan. BMC Infectious Diseases 2012 12:82.

\section{Submit your next manuscript to BioMed Central and take full advantage of:}

- Convenient online submission

- Thorough peer review

- No space constraints or color figure charges

- Immediate publication on acceptance

- Inclusion in PubMed, CAS, Scopus and Google Scholar

- Research which is freely available for redistribution 